\title{
THE SPIRITUAL FOUNDATIONS OF A DEMOCRATIC SOCIETY
}

\author{
Rustam Norliev
}

Associate Professor Of Philosophy Head Of The Department Of Civil Society, Termez State University, Uzbekistan Oydin Ibragimova

Student Termez State University, Uzbekistan

\section{ABSTRACT}

The article discusses the spiritual foundations of building a "democratic state based on the rule of law" in Uzbekistan during the years of independence, the restoration of historical heritage and its importance. It also discusses works in the restoration of historical heritage and its significance.

KEYWORDS: - Spiritual foundations, democracy, democratic state, heritage, democratic society, "Uzbek model", civil society, public institutions, cultural values, national holidays.

\section{INTRODUCTION}

A society based on democratic principles cannot imagine its future without developing and strengthening its spiritual potential, spiritual and moral values in the minds of the people. The spiritual heritage of the people's cultural values has served as a powerful source of spirituality for the peoples of the East for thousands of years. Despite the long-lasting ideological pressure, the people of Uzbekistan have managed to preserve their historical and cultural values and unique traditions that have been passed down from generation to generation.

Changes and innovations in the world and in the life of Uzbekistan have radically changed our perception of social development and aroused great interest in knowing the objective laws of formation and development of democratic processes. In establishment a democratic society, Uzbekistan "...decided to abandon the old dictatorial Soviet system, which has survived since the early days of independence, to build an open democratic state and civil society based on a socially oriented market economy".

After our people gained their independence, the attitude to the history of the country, its rich historical heritage, spiritual values and traditions has changed radically. As described in the book of the head of state «High spirituality is an invincible force ", attention was drawn to one of 
CURRENT RESEARCH JOURNAL OF PEDAGOGICS 2(12): 130-134,

December 2021 DOI: https://doi.org/10.37547/pedagogics-crjp-02-12-26

ISSN 2767-3278

(C)2021 Master Journals

Crossref dof 81 Google

Accepted 20 th December, 2021 \& Published 25 th December, 2021

the priorities of spirituality - a unique force that encourages spiritual purification, growth of the soul, strengthens the inner world, will, faith and conscience [1, p. 27]. During the Soviet era, historical facts that discriminated against and distorted our nation and people were restored. National holidays and traditions have returned to their original state. The mausoleums, mosques and madrasas of our saints, which were neglected and almost on the verge of extinction, have been completely renovated.

\section{THE MAIN FINDINGS AND RESULTS}

After gaining independence, the world has chosen the path of development, which is called the "Uzbek model", abandoning the commandand-control, planned-distribution system. The essence of this model, developed by the first President and consistently implemented, is to radically change and modernize state building and the constitutional order, to free the economy from ideology, to ensure its supremacy over politics, to fulfill the main reform task of the state. , ensured the rule of law, pursued a strong social policy, and carried out political, economic, and social reforms based on the principles of gradual and consistent reform [2, pp. 335-342].

The adoption of the Decree of the President of the Republic of Uzbekistan Shavkat Mirziyoyev on February 7, 2017 "On the Strategy for further development of the Republic of Uzbekistan" also identified priorities for socio-economic development of the country [3, pp. 21-53]. At the same time, this path is undoubtedly a strategy to build a new life, a new society in our country, to bring our country to the ranks of modern developed countries. Gradual and gradual change, based on the harmony of national and universal values, taking into account the mentality of the people and the existing conditions, the reforms serve the interests of man and his rights, his physical and spiritual development, the needs of all segments of society and the welfare of the people. it shows how comprehensive this doctrine consists of a system of concepts and principles and views.

From the first days of independence of the Republic of Uzbekistan, the restoration of the immense, invaluable spiritual and cultural heritage created by our ancestors for many centuries and respect for national and universal values has risen to the level of state policy [4, pp. 281-286].

Strengthening independence requires the solution of a number of problems and tasks related to the radical historical turn in the political, economic, cultural, spiritual aspects of society. Such a huge task and responsibility requires our people, on the one hand, to fully understand the process of spiritual renewal, and on the other hand, to rely on it in building a democratic society. After all, national-spiritual renewal is becoming a factor of growth and democratic development. Therefore, the recreative assimilation of the heritage of our great scientists, who made a significant contribution to world civilization during the years of independence, has become a vital necessity. In particular, Imam Bukhari, Imam at-Termizi, Hoja Bahouddin Naqshband, Hoja Ahmad Yassavi, AlKhwarizmi, Ahmad Fergani, Beruni, Ibn Sina, Amir Temur, Mirzo Ulugbek, Alisher Navoi, Zahiriddin Muhammad Babur, Abdulla Qodiri, Chulpan, Fitrat, Behbudi, Usman Nasir and many other great figures forms the national and spiritual basis of the democratic society being built in our country. From the first days of our independence, the restoration of the immense, invaluable spiritual and cultural heritage created by our ancestors over many centuries has become an extremely important task that has risen to the level of state policy.

We consider the restoration of spiritual values as an integral, natural process, consisting of the 
CURRENT RESEARCH JOURNAL OF PEDAGOGICS 2(12): 130-134,

December 2021 DOI: https://doi.org/10.37547/pedagogics-crjp-02-12-26

ISSN 2767-3278

(C)2021 Master Journals

Crossref do: 81 Google

Accepted 20 th December, 2021 \& Published 25 th December, 2021

growth of consciousness of national identity, the return to the spiritual origins of the people, its roots. Emphasizing the same aspect of the issue, the President of our country I.Karimov in his book "Uzbekistan aspires to the XXI century" has a huge task to fulfill the six priorities. After gaining political independence and freedom, our people became the true masters of their own destiny, the owners of a unique national spirituality and culture [5, pp. 137-138].

In the process of spiritual growth, the dialectic of universal and national values develops in all spheres of national development, gaining social meaning. The task of building a democratic civil society in Uzbekistan cannot be accomplished without spiritual renewal. That fact must never be forgotten. Democracy is a culture of people living together, solving problems together, and seeing personal interests in line with the interests of the community, the nation, the state, the culture of compromise [6, pp 79-82].

During the years of independence, a new, improved system of spiritual and educational work in accordance with the requirements and interests of the time was formed. Hundreds of museums, houses of culture and palaces, information resource centers, parks of culture and recreation began to provide spiritual and educational services to our compatriots as public institutions. The Republican Center for Spirituality and Enlightenment was established (1994) and its regional, district and city branches were launched. In accordance with the Decree of the President of the Republic of Uzbekistan dated August 25, 2006 "On increasing the effectiveness of the promotion of national ideas and spiritual and educational work", the activities and structure of the Republican Council for Spirituality and Enlightenment were revised. A system of advisers on spiritual and educational work of elders of "Mahalla" and chairmen of citizens' assemblies has been formed in the country [7, pp. 9-12].
A number of positive measures have been taken to develop and increase the effectiveness of spiritual and educational work. With the participation of spiritual and educational institutions operating in all regions, major cities and districts of the country, large folk festivals, harvest festivals, "Independence", "Navruz", "Mehrjon" holidays, the International Festival "Sharq Taronalari", singers, dancers, the best professionals There are contests "Uzbekistan is my homeland", "The greatest, the dearest", "Voice of the Future" and others [8, p. 11]. During the years of independence, the Turkiston Palace, the Alisher Navoi National Park, the State Museum of the History of the Temurids, the National Academic Theater and the new building of the State Conservatory of Uzbekistan, as well as many other facilities have been built in Tashkent.

The first President of Uzbekistan Islam Karimov wrote in his book "High spirituality is an invincible force": "Great scholars, nobles, scholars, politicians, commanders have emerged from this ancient and sacred soil. The foundations of religious and secular sciences were laid in this country. The waterworks built before and after our era, which have not lost their charm and majesty to this day, testify to the high level of agriculture, handicraft culture, architecture and urban planning in our country since ancient times. More than 20,000 manuscripts that have survived the trials of the period, from the oldest stone inscriptions to inscriptions, are in the treasury of our libraries today. Thousands of works of art are our incomparable spiritual wealth, our pride. A nation with such a great heritage is rare in the world. Therefore, I can say that only a few countries in the world can compete with us in this regard. It is time to seriously study these rare manuscripts, which embody the centuriesold life experience, religious, moral and scientific views of our ancestors" [9, p 67-71]. 
CURRENT RESEARCH JOURNAL OF PEDAGOGICS 2(12): 130-134,

December 2021 DOI: https://doi.org/10.37547/pedagogics-crjp-02-12-26

ISSN 2767-3278

(C)2021 Master Journals

Crossref dof 81 Google

Accepted 20 th December, 2021 \& Published 25 th December, 2021

In the process of spiritual ascension, the dialectic of universal and national values is the same in content, but different in form. For example, among the forms of manifestation of universal values, many have a positive priority. In particular, a person's life, sociality, life, health, activity, labor, knowledge, and behavior are important among the universal values. These values, as long as man and society exist, retain their social significance, as opposed to death, disease, meaningless living, ignorance, and so on, are constant companions of historical processes [10, pp. 359-362]. Of course, it is the civic duty of all of us to study and carefully preserve all the objects and evidences that have become our cultural heritage from the history of our people, our gray masterpieces and architectural monuments, our ancient traditions that are the basis of our national values.

\section{Conclusion}

"National values" - the material and spiritual wealth created by a nation in the process of natural, historical and social development, the region in which it lives, cultural and spiritual heritage, national culture, language, national consciousness, national spirit, history, way of life, national order. -rules and the concept that reflects the social significance of the features and aspects associated with them. It is a feature of the system of universal values, that is, it reflects the most general aspects of the values inherent in the nation.

The economic basis for building a democratic state and civil society based on the rule of law has been created in our country, political systems and institutions have been formed, and their organizational and legal bases have been created. The practical expression of the idea of the head of our state "From a strong state to a strong civil society" is proving itself. Undoubtedly, these innovations give endless pride to each of our compatriots who call themselves generation of this country, in turn, impose a great responsibility on us and encourage us to live selflessly in the pursuit of this noble goal, to preserve the achievements. National values are manifested in different forms, in an integral relationship with each other, that is, they form a unique system of national values. The values that ensure naturalhistorical unity in this system are unity, cultural and spiritual closeness, past and spiritual heritage, a sense of homeland.

\section{REFERENCES}

1. Pomfret, R. (2000). The Uzbek model of economic development, 1991-91. Economics of Transition, 8(3), 733-748.

2. Расулов, Х. (2021). Хуқуқий маданият: муаммонинг ижтимоий-сиёсий омиллари. Общество и инновации, 2(10/S), 335-342.

3. Prezidentining, O. Z. R. (2017). yil 7 fevraldagi PF-4947-son “0 'zbekiston Respublikasini yanada rivojlantirish bo 'yicha Harakatlar strategiyasi to 'g 'risida" gi Farmoni. 0 'zbekiston Respublikasi qonun hujjatlari to 'plami.

4. Hakim, R. (2021). Political and Legal Culture-the Factors of Stability of the Political and Legal System. Бюллетень науки и практики, 7(3), 281-286.

5. Каримов, И. А. (1997). Ўзбекистон XXI аср бўсағасида: хавфсизликка тахдид, барқарорлик шартлари ва тараққиёт кафолатлари. Тошкент: Ўзбекистон, 326.

6. Kushokov, S. Y., \& Ahmedov, S. (2021). The structure of turkish tribes in Central Asia and its historical importance.

7. Ernazarov, D. (2020). ED Фуқаролик 
CURRENT RESEARCH JOURNAL OF PEDAGOGICS 2(12): 130-134,

December 2021 DOI: https://doi.org/10.37547/pedagogics-crjp-02-12-26

ISSN 2767-3278

(C)2021 Master Journals

Crossref doi) 81 Google

Accepted 20th December, $2021 \&$ Published 25th December, 2021

жамияти институтлари фаолиятида

ёшларнинг иштирокини таъминланиш

масалалари. Архив научных

исследований.

8. Totliboyevna, R. A. (2021). The Importance of National Values in Strengthening Uzbek-

Family Relations. Middle European

Scientific Bulletin, 11.

9. Каримов, И. (1998). Тарихий хотирасиз келажак йўқ. Тошкент. Шарқ.

10. Mamanovich, R. H. (2021). Civil Society:

Prosperities of Decentralization in

Management. Middle European Scientific

Bulletin, 18, 359-362. 